\title{
Universiteit
}

Leiden

The Netherlands

\section{Beyond the dichotomy of liberal and illiberal migration governance}

Natter, K.; Carmel, E.; Lenner, K.; Paul, R.

\section{Citation}

Natter, K. (2021). Beyond the dichotomy of liberal and illiberal migration governance. In E. Carmel, K. Lenner, \& R. Paul (Eds.), Elgar Handbooks in Migration (pp. 110-122). Cheltenham: Edward Elgar Publishing. doi:10.4337/9781788117234.00015

Version:

License:

Downloaded from:
Publisher's Version

Licensed under Article 25fa Copyright Act/Law (Amendment Taverne)

https://hdl.handle.net/1887/3239101

Note: To cite this publication please use the final published version (if applicable). 


\title{
9. Beyond the dichotomy of liberal and illiberal migration governance
}

\author{
Katharina Natter
}

\section{INTRODUCTION}

What shapes migration policymaking across the globe? Is migration governed in fundamentally different ways by democracies and autocracies? Does liberal democracy have an in-built drive towards expansive immigration policies? These questions go to the core of the scholarly debate on the role of political regimes in migration governance.

This chapter critically reviews the scholarly debate as it has unfolded since the early 1990s. It starts by outlining how the dominant scholarly focus on 'Western liberal democracies' has created a set of assumptions about the effects of political regimes in immigration policy. Most importantly, the 'liberal paradox' argument has tied the institutions and practices of democracy (assumed to be in 'the global North') to liberal immigration policy, and - by implication - it has suggested that autocracies (assumed to be in the 'global South') have an in-built tendency to produce immigration restrictions.

Since the 2000s, research has started to overcome this Western-centric worldview by investigating migration politics in Latin America, Asia and Africa. Some scholars have advanced the argument that there is an 'illiberal paradox' of autocratic migration governance, in order to capture the contradictory dynamics that autocracies face when designing their immigration and emigration policies. However, both research strands - on 'Western liberal democracies' as well as on 'autocratic' regimes - remain ultimately within a binary logic that splits the world into 'global North/global South' or 'democracy/autocracy'. They are also often influenced by methodological nationalism and therefore overlook the transnational dynamics that shape migration governance within and between countries. This prevents the cross-fertilization of empirical insights, as well as theory-building across political regimes and political geographies.

To pave the way for a global study of migration governance, the chapter mobilizes insights from postcolonial studies to discuss the political economy of knowledge production that underlies this methodological nationalism and binary worldview dominating much of the migration literature. It ends by outlining the pillars of a critical research agenda that deliberately 'crosses boundaries' to highlight the fluidity and ambiguity of migration governance practices and to identify similarities in policymaking across political regimes, as well as variations within a particular polity. Such research could, for instance, shed light on illiberal migration policy practices in formal democracies or on liberal migration policy practices in formal autocracies. It could also advance theorizing on the increasingly selective nature of immigration policies along skill, class, nationality and vulnerability criteria, which is obscured by homogenizing concepts such as 'restrictiveness' or 'openness' that miss the differentiated inclusion/exclusion dynamics at play. This would open up new perspectives on contemporary migration politics worldwide. 


\section{THE ROOTS OF THE DEBATE: THE STATE FORMATION- MIGRATION POLICY NEXUS}

If we look back in time, migration governance - the formal laws and informal practices that regulate the entry and stay of foreigners, and the exit of citizens - emerged together with the modern nation-state. Feudal empires were defined through their (geographical and political) centres and often had shifting or porous territorial borders. Political belonging and allegiance could change over a person's lifetime and was largely determined by which sovereign could guarantee economic survival and offer effective protection from physical violence. In contrast, the modern nation-state that became the dominant form of statehood in the nineteenth century conceived sovereignty as the monopoly of political power over a specific human community and within a given territory (Weber 2009 [1919]: 78). This shifted the focus from the state's centre to its borders and, over time, turned national territory and national population into core elements of statehood (Torpey 1997). Defining who is part of the nation and who is not, and controlling the movement of people across borders - nationals and foreigners alike - was thus crucial to the idea and formation of modern national statehood (see the extended discussion by El Qadim in this volume, Chapter 19).

Until the mid-nineteenth century, migration control by European imperial states was mainly concerned with regulating the departure of citizens, because manpower determined the strength of the national army and many European nation-states were colonial empires that actively pursued the settlement of lands in Asia, Africa and Latin America. Thus, they were more concerned with encouraging emigration and regulating mobility through slavery and indentured labour than with controlling immigration (Zolberg 1978). Those states that did have active immigration policies in the nineteenth century - such as the United States, Argentina, Brazil, Mexico and Australia - encouraged the settlement of 'racially desirable' migrants from North and Western Europe who would 'populate' the (supposedly unpopulated) vast interior lands of these countries, exploit their fertile soils and contribute to the political project of 'whitening' the population. (The fundamental roles of colonization and colonialism to migration governance and politics are further discussed by Mayblin in this volume, Chapter 2.)

Democratization claims in Western Europe and North America made it increasingly difficult to justify state control over the exit of citizens: after the 1789 French Revolution, for instance, the freedom to circulate on, and leave, French (including colonized) territory for Metropolitan French citizens was enshrined in the 1791 Constitution (Torpey 2000: 29). As we will see later, this tension between democratic demands, human rights imperatives and migration control ambitions remains to the present day. In addition, the spread of racist ideology from the 1870s onwards led to a "globalization backlash" (Timmer and Williams 1998): state priorities shifted from emigration to immigration control, passports were introduced and legislation enacted to ban the entry of people from certain races, origins or social classes - such as the 1882 Chinese Exclusion Act in the United States or Australia's Immigration Restriction Act of 1901, which excluded all 'non-white' people from immigrating and prohibited the entry of criminals and prostitutes.

Immigration controls became even more central to nation-state building when the geography of global migration was reversed with decolonization in the 1950s and 1960s: while Europe was a continent of emigration over the eighteenth and nineteenth centuries, it became a continent of immigration after the Second World War, with migrants coming from an increasingly wide range of countries (de Haas et al. 2019). With Europeans emigrating less, immigration 


\section{Handbook on the governance and politics of migration}

to the United States and Australia became increasingly Latin American and Asian, respectively. In the Arabian Peninsula, the discovery of large oil reserves in the 1970s transformed Gulf countries into major immigration hubs for workers from the Middle East and Asia. At the same time, migration within the Soviet bloc was actively encouraged by political leaders during the Cold War, through formal student exchanges and recruitment programmes between Cuba, Vietnam, Mozambique, the German Democratic Republic and Czechoslovakia. More recently, Asian countries such as South Korea, Singapore and Malaysia have become major immigration destinations, and recurrent wars and civil conflicts have turned Middle Eastern and East African countries such as Uganda, Sudan, Lebanon and Turkey into the world's largest refugee hosts.

Together, these migration trends have created new incentives for nation-states around the world to regulate immigration, to develop ever-more sophisticated policies to monitor borders and to differentiate entry rights of migrants according to origin, class or skills (de Haas et al. 2018). This historical context of nation-state formation, within which migration governance emerged and developed, also crucially informed the study of migration politics - which questions were asked, what cases studied - and, ultimately, produced the biases underlying the idea of an il/liberal paradox in migration governance.

\section{THE CORE OF THE DEBATE: THE LIBERAL PARADOX}

The nexus between nation-state formation and the emergence of migration governance raises the following question: do specific nation-state features - such as the definition of political membership or the type of political regime in place - shape the way in which migration is regulated, and if so, how?

Looking at emigration policy, the answer seems to be yes. As mentioned earlier, the abolition of exit controls for citizens of European states was tightly linked with democratization tendencies and the protection of human rights, and (originally) colonial expansion. Even in the context of the COVID-19 pandemic, democratically elected leaders have a hard time justifying why the state can limit the freedom of movement of its citizens, as the 'right to leave' is enshrined in article 13 of the United Nations' 1948 Universal Declaration of Human Rights. It is also telling that countries in Eastern Europe and Central Asia rapidly dismantled exit restrictions after the fall of the Soviet Union in the early 1990s, in the context of democratization, and that most countries who continue to restrict exit - such as North Korea, Eritrea and Saudi Arabia - are fully-fledged autocracies (de Haas and Vezzoli 2011).

The link between political regimes and immigration policy is more contested. In the early 1990s, a scholarly debate emerged about how liberal democracy shapes immigration policy. At that time, migration scholars in Western Europe were trying to understand the 'liberal turn' they observed in labour and family immigration policies: why did political leaders continue to progressively liberalize immigration policies - by creating new immigration opportunities and expanding migrants' socio-economic and political rights - despite citizens' political opposition to such liberalization?

Hollifield (1992) introduced the 'liberal paradox' concept to account for the difference between citizens' political demands and enacted migration policies. He argued that liberal democracies were confronted with contradictory forces when designing immigration policies: on the one hand, the 'democratic' component of liberal democracy would motivate politicians 
to adopt restrictive stances on immigration because of nationalist, protectionist demands by citizens and political leaders' dependence on re-election. On the other hand, the 'liberal' component of liberal democracy would push politicians to adopt open immigration reforms because the state's insertion in global capitalist market economies required political leaders to meet businesses' labour needs, and because the adherence to international human rights standards and liberal norms would limit the state's possibilities of migration control.

The two facets of liberal-democratic politics - liberalism and democracy - thus seem to work in different directions when it comes to immigration: pro-immigration reforms are credited to national business interests or (international) human rights norms, while anti-immigration reforms are ascribed to election cycles, party politics and public opinion (cf. Guia in this volume, Chapter 33). This dynamic would also explain why there is a 'discursive gap' between the tough anti-immigration rhetoric that many policymakers adopt in public and the generally more liberal immigration regulations that are ultimately enacted - as the policymaking process in-between requires decision-makers to take into account a range of different and often diverging interests (Czaika and de Haas 2013; Massey et al. 1998).

Migration policy research since the 1990s has provided valid reasons to criticize and nuance the 'liberal paradox' argument. For instance, public opinion is not necessarily always against immigration (Bonjour 2011: 111) and economic actors might in fact not lobby for immigration liberalization, as they prefer to hire irregular migrant workers who lack socio-legal protections (Piore 1979; Ruhs and Anderson 2010). Also, Acosta Arcarazo and Freier (2015) have shown that, in Brazil and Argentina, the discourses of democratically elected leaders on immigration have - at least up to the mid-2010s - been more liberal than the policies implemented on the ground (see also Guia in this volume, Chapter 33) which is the reverse of what Hollifield's 'liberal paradox' would predict. Most importantly, perhaps, the 'liberal paradox' homogenizes immigration policies and fails to attend to their inherently differentiated and selective nature (de Haas et al. 2018). Indeed, various levels of immigration openness and closure coexist next to each other, because the categorization of migrants as, for example, asylum seekers, family members, or high- and low-skilled workers, creates varied dynamics of inclusion and exclusion (see Bakewell, Chapter 10; Bonjour and Cleton, Chapter 13; Vasey, Chapter 14, all in this volume). Regardless of these limitations, however, the 'liberal paradox' has become one of the most important concepts in political science migration studies over the past decades and spurred a wealth of research and debate on the drivers of immigration policy in liberal democracies.

To explain why, over the 1990s, the liberal, pro-immigration component ultimately seemed to prevail over the democratic, anti-immigration component, scholars have advanced a series of theoretical explanations. These all put the institutional dynamics and practices of liberal democracy centre stage: Freeman (1995) argued that "client politics" dominates immigration policymaking in liberal democracies, with the two main clients making opposing demands. According to him, employers and migrant associations (the "beneficiaries of immigration") tend to favour immigration liberalization, while the wider electorate (that "bear[s] the costs of immigration") is likely to favour immigration restrictions. Policymakers, in turn, tend to privilege the interests of those who can lobby effectively. In the 1990s, these were the pro-immigration advocates, whose lobbying capacity within the state bureaucracy by far exceeded that of the electorate, which at the time remained at a structural disadvantage to make its voice heard. 


\section{Handbook on the governance and politics of migration}

Joppke (1998) and Guiraudon (1998) have complemented this political economy argument with an institutionalist perspective, stressing the rule of law as an important explanation for the 'liberal turn'. According to them, national courts and judges have played a key role in enshrining migrants' rights to permanent residency, family reunification or social protection against attempts from other institutions, such as the Ministries of Interior or Social Affairs, to restrict those rights (see the discussion on legal mobilization in Kawar in this volume, Chapter 31). The judgments of American courts that cancelled certain immigration restrictions enacted by the Trump administration since 2017 offer prime examples of this dynamic. Also, supra-national courts such as the European Court of Justice (ECJ) have regularly overturned national legislation and policy practices, most prominently in the area of family reunification, where the ECJ has consistently upheld the right to family life enshrined in article 8 of the European Convention of Human Rights.

Although they zoom into different dynamics within the policymaking process, these theoretical explanations all emphasize the role of liberal democracy in constraining the possibilities of nation-states to restrict immigration. Ultimately, scholars have suggested the existence of a 'regime effect' by tying immigration liberalization to particular institutional and political dynamics within democracies, such as the role of courts, employers or civil society activism. Some have even explicitly argued that "accepting unwanted immigration is inherent in the liberalness of liberal states" (Joppke 1998: 292). This has two important theoretical consequences: it suggests not only that (1) immigration governance in autocracies is driven by fundamentally different dynamics that require a separate set of analytical tools and theories, but also (2) that in countries where such 'unwanted' immigration is no longer accepted, the liberalness of liberal democracies is at stake.

\section{THE BIAS OF THE DEBATE: A FOCUS ON 'WESTERN LIBERAL DEMOCRACIES'}

In contrast to the global nature of migration, the academic discussion on migration governance, certainly outside 'forced migration studies', has largely focused on immigration policymaking in consolidated liberal democracies across Western Europe and North America (Boswell 2007; Castles 2004; Hampshire 2013). Research on 'counterfactuals' that would systematically investigate immigration policymaking in autocracies or 'non-Western' democracies remains very limited and its incipient insights scattered across disciplines or world regions. This is not only problematic because almost one out of two international migrants live in the 'global South' and nearly half of the countries worldwide are classified as autocracies or hybrid regimes. This bias is also problematic because it means that the argument of a 'regime effect' in immigration policymaking is based on researching 'one side of the coin' only - 'Western liberal democracies'.

These biases and the claim of Western liberal democracies' exceptionalism, reflect two assumptions deeply rooted in scholarly and political migration debates, namely (1) that the world is split into immigration countries in the economically advanced 'global North' and emigration countries in the developing 'global South' and (2) that there is an overlap between political systems and political geographies, with countries in the 'global North' assumed to be liberal democracies and countries in the 'global South' autocracies or at best malfunctioning democracies. These assumptions are misleading. They ignore that some of the world's major 
immigrant destinations (such as Saudi Arabia, Malaysia, Jordan and Singapore) are by no means 'Western liberal democracies'. In addition, this binary worldview hides the existence of liberal democracies in the 'global South' (such as Uruguay, India - until recently - and Botswana), as well as recent autocratic histories and contemporary autocratic tendencies in 'Western liberal democracies' (most prominently in Hungary or the United States). Ultimately, the liberalness of liberal democracy is not as stable as is often implicitly assumed in the debate.

The rationale for separating the 'West' from the 'Rest' is thus primarily rooted in global power dynamics and not in the analytical utility of these concepts. The term 'global South' covers countries as economically, politically, geographically and culturally different as Morocco, Indonesia and Kazakhstan. Also, depending on the indicator chosen - income levels, human development, geography or geopolitical alliances - the lines demarcating 'global North' from 'global South' constantly shift (Bakewell 2009). The 'global South' is thus not defined substantially, through a shared set of characteristics, but relationally, through its opposition to and history of colonialization by the 'global North' (Comaroff and Comaroff 2012: 127). Similarly, or perhaps even more so, the 'global North' is rarely explicitly defined or theorized. This term is generally used as a shortcut to capture an 'exclusive club' of countries - essentially North and Western Europe, North America, Australia and New Zealand, sometimes also Southern and Eastern Europe or South Korea and Japan (Natter 2018b). This conceptual homogenization disregards that actual political systems across those countries display large variations with regard to electoral rules and party systems, not to mention the difference between parliamentary and presidential systems or the existence of constitutional monarchies.

Ultimately, both the 'Western liberal democracy' and the 'global North/global South' categories are deceptive; not only because they misrepresent reality, but mainly because they do not offer productive intellectual tools to understand migration governance in the past and today, as they conceal differences within and similarities among those reified groups. They are often methodologically nationalist, and therefore risk missing the transnational policies and practices that shape migration governance within and between countries (also see Fischer in this volume, Chapter 4). A short detour on the political economy of knowledge production is necessary to explain the consequences of such a biased terminology for social scientific theory-building.

\section{THE CHALLENGE: DEFYING THE POLITICAL ECONOMY OF KNOWLEDGE PRODUCTION}

Social theory is about making sense of what is out there in the world by uncovering patterns in social behaviour. Like novels, whose particular stories can speak to readers across space and time if they get to the core of human and societal relations, social theory can be universal in scope. At the same time, it is never finished. It continuously evolves as new people join the scientific endeavour and bring in their worldviews and experiences. Yet, not all experiences and worldviews are given similar weight in knowledge production. The effect of global inequalities is particularly strong when it comes to which research questions are investigated, and who can contribute to theory-building. With most scientific resources concentrated in Europe and North America, the political economy of migration research can largely explain the disproportionate attention given to immigration policymaking in 'Western liberal democracies' and the concomitant claim of their exceptionalism (for an early critique of such knowledge 
production dynamics in the field of refugee studies, see Chimni 1998). It is in this way that social theory, and the concepts it produces, reflect global power structures.

Criticism of such Western-centrism in social theory is not new (Wallerstein 1997). Over the past decades, postcolonial scholars - both from within and outside the West - have challenged the Western monopoly of knowledge and the assumption that a 'universal social theory' could be based on Western experiences only. There are two main suggestions within post-colonial social science on how to move beyond Western-centrism: On the one hand, scholars have highlighted the diversity of epistemologies around the globe and advocated the need to 'decolonize' theory (Mignolo 2002) or to 'provincialize' knowledge (Chakrabarty 2000). The idea of provincialized theories is appealing, but it ultimately abandons the ambition of generalizability and continues to analyse experiences around the world through separate theoretical lenses. On the other hand, scholars have called for 'opening up' the social sciences by expanding theories from a Southern perspective and moving towards a more global social science (Bhambra 2014; Connell 2007). Here, the focus lies on creating dialogue between different ways of analysing the world. The ideal outcome of such a dialogue would not be to merely add new elements to existing theory, but to (re)build theory with global relevance through connecting and integrating previously side-lined empirical and conceptual knowledge (Bhambra 2014; compare Mayblin in this volume, Chapter 2).

But what does it mean in practice to move towards a more global social science? First, it requires breaking the unidirectional application of theory from 'North' to 'South' and to foster theoretical innovation through 'reciprocal comparisons' that "view both sides of the comparison as 'deviations' when seen through the expectations of the other, rather than leaving one as always the norm" (Pomeranz 2000: 8). Second, moving towards a more global social science requires opening our eyes to, and systematically looking for, similarities where we would not expect them. Indeed, it is not enough to denounce the political dynamics that underlie binary worldviews. In order to discard such categories, scholars need to prove their empirical irrelevance for explaining real-life patterns and dynamics.

In migration studies, scholars have started to investigate the dynamics and drivers of migration politics in countries commonly categorized as 'Southern' or 'autocratic'. Such studies of 'the other side of the coin' have played an important role in redressing the 'Western' bias in migration research. Yet, they often remain trapped within a binary worldview and therefore prone to similar limitations than research on 'Western liberal democracies', namely methodological nationalism and cultural essentialism. More recently, therefore, scholars have started designing research that deliberately crosses the boundaries that structure migration research in order to highlight the fluidity and ambiguity of migration governance practices and to showcase similarities in immigration policymaking across pre-set categories. The final two sections introduce these emerging literatures, showcase their innovative insights as well as their limitations, and outline the novel questions they raise.

\section{INVESTIGATING 'THE OTHER SIDE OF THE COIN': THE ILLIBERAL PARADOX}

Since the mid-2000s, scholars started to redress the bias towards 'Western liberal democracies' in migration studies, first by investigating emigration and diaspora policies (Brand 2006; Gamlen 2008), then also by studying immigration and refugee policies in Africa, Asia and 
Latin America. Their research challenges the existence of a clear 'regime effect' that would tie liberal immigration policies to democratic political systems, and restrictive immigration policies to autocratic regimes. For example, FitzGerald and Cook-Martín (2014) compared immigration policymaking in the Americas over the past two centuries and demonstrate that racist selection criteria in immigration policies were in fact promoted by democratic institutions in late nineteenth-century North America, while it was precisely the autocratic nature of governments in Brazil or Mexico during the 1960s and 1970s that allowed them to abolish ethnic discrimination and adopt anti-racist immigration policies - at least on paper. Looking at refugee politics in Tanzania, Guinea and Kenya, Milner (2009) also shows that democratization can lead to restrictive policy changes while autocracies sometimes have more leverage to enact liberal policies towards refugees.

Other scholars have zoomed into autocratic countries' migration politics, highlighting trends that seem to diverge from those observed in 'Western liberal democracies'. Thiollet (2016), for instance, shows that - in contrast to the cosmopolitan, liberal character of transnationalism discussed in the mainstream literature - transnational private actors and states in the oil-rich Gulf have actually fostered regional integration through restrictive migration governance, a trend she coins 'illiberal transnationalism'. And Norman (2016) has argued that autocratic leaders in Morocco, Turkey and Egypt deliberately pursued a policy of 'ambivalence' towards migrants (by granting them rights through ad hoc or informal decisions instead of legal changes) to increase their leeway to cancel these rights in the future (see also Natter 2021, Stel 2020). Looking at immigration policy developments in a range of 'Western liberal democracies' over the 2010s, however, these dynamics seem less tied to the political regime in place than expected at first. In Southern European countries, immigration regulations have often remained at the level of informal practices and ad hoc policy changes, while, in the United States, immigration restrictions have often been enacted through presidential decrees or other executive instruments and not through parliamentary law-making. In addition, the restrictive immigration policies enacted by democratically elected governments in Hungary, the UK, Denmark and Italy seem to have fostered a particular kind of European regional integration - based on nationalism and an anti-immigration rhetoric - that resembles Thiollet's 'illiberal transnationalism' in the Gulf.

Bringing together these empirical insights and mobilizing the 'liberal paradox' concept, scholars have suggested the existence of an 'illiberal paradox' in autocratic migration governance. On emigration and diaspora policies, Tsourapas (2019: 4-5) has argued that autocracies face a trade-off between maximizing the economic gains of emigration and safeguarding national security as well as domestic regime survival. He shows that authoritarian states that do not seek to attract economic remittances by emigrants are likely to restrict their emigration policies to prevent people from leaving in the first place (such as North Korea and the former Soviet Union). In contrast, states that privilege the economic gains of emigration will likely refrain from restricting emigration and instead focus on controlling their diasporas to limit political claims-making from abroad (such as Eritrea, Morocco and China).

With regard to immigration policies, Natter (2018a) has argued that autocracies are bound by global economic liberalism in similar ways than liberal democracies and thus face the same incentives for immigration openness. However, they are more independent from democratic dynamics that are said to drive immigration restrictions - such as election cycles and public opinion - or from the legal activism of national courts that seem specific to countries with a strong rule of law. Although autocratic leaders also have to reconcile the diverging interests 
of economic and institutional actors, ultimately they can enact open immigration reforms more easily than their democratic counterparts. This is the core of the 'illiberal paradox' hypothesis: it does not imply that autocracies do enact more liberal policies than democracies, but it suggests that autocracies can liberalize their immigration rules more easily than democracies if they wish so, that is, if it fits the broader economic goals, foreign policy agenda, or domestic political priorities of the regime in place.

Libya is a case in point: over the 1990s, Libya has actively pursued an open-door policy towards migrant workers from sub-Saharan Africa, as part of Ghaddafi's turn in foreign policy from pan-Arabism to pan-Africanism (Paoletti 2011). As a result, over 2.5 million foreigners, most of them from sub-Saharan Africa, were living in Libya at the turn of the twenty-first century. Similarly, the liberal immigration reform launched by the Moroccan king in September 2013 was mainly driven by foreign policy interests: the two regularization campaigns for undocumented migrants and the granting of socio-economic rights to migrants broke with the restrictive approach of the previous decades and allowed Morocco to reposition itself geopolitically in front of both European and African partners (Natter 2018b). These instances show the extent to which autocratic policymaking allows state actors to privilege strategic and foreign policy interests over domestic demands and thus to liberalize migration without the fear of future electoral losses.

However, the 'illiberal paradox' argument has three main limitations that in part mirror those of its counterpart, the 'liberal paradox': first, welcoming discourses might primarily fulfil a symbolic role, leading to a 'discursive gap' between open discourses on immigration and the often more restrictive policy practices on the ground. Second, because autocracies are less bound by legal constraints than democracies, liberal immigration reforms are particularly vulnerable to sudden restrictive backlashes and to shifting state priorities. Third, immigration and integration rights do not automatically go hand in hand. As Ruhs (2013) has argued with regard to low-skilled labour immigration, states are faced with the choice of allowing high immigration and restricting integration rights, or limiting immigration and offering integration rights. Because of this numbers vs. rights trade-off, enacting liberal immigration reforms might be particularly attractive for autocracies with low immigration numbers or where political leaders can avoid that open entry policies spill over into a general liberalization of migrants' rights.

\section{THE WAY FORWARD: CROSSING BOUNDARIES}

The aim of such conceptual debates around 'transnational illiberalism' or the 'illiberal paradox' is to specify the role of autocracy in migration governance. Yet, while studies that look at 'the other side of the coin' redress the Western liberal-democratic bias of mainstream migration governance research, they still operate within a binary worldview that essentializes categories such as 'global North/global South' and 'democracy/autocracy'. This ultimately limits the questions that can be asked and the insights that can be gained, as it disregards the complexity and ambiguity of migration governance across political regimes and political geographies. This section outlines two research strategies that allow migration scholars to more effectively overcome such bias: (1) looking at variations in policymaking within a given polity and (2) studying countries comparatively across assumed divides. 
The first research strategy that can contribute to critical theory-building on migration governance is to zoom into the variations of migration policy dynamics within a specific polity. Not all policy issues around immigration are subject to the same dynamics: the institutional, international and civil society actors engaged in refugee integration are different from those engaged in low-skilled labour migration or student mobility. The interests pursued and ideas mobilized by those actors vary, as do the legal, economic and moral foundations that frame policymaking on a particular issue. Not acknowledging coexisting policies of closure (for some) and openness (for others) represents a significant blind spot in the mainstream political science literature (on the complexity and dynamism of border regimes see also Rajaram in this volume, Chapter 15). Immigration policy research could therefore benefit from a more systematic and fine-grained analysis that unpacks homogenizing concepts of 'overall restrictiveness' or 'overall openness' (see de Haas et al. 2018) and attends more closely to the variation in political and policymaking dynamics according to the migrant categories or policy areas at stake.

As I have suggested elsewhere (Natter 2018b), theory-building on immigration policymaking could be advanced through the following, three-fold typology that distinguishes generic, issue-specific and regime-specific policy processes: (1) 'Generic' policy processes are at play regardless of the political regime in place or the policy issue at stake, because they emerge out of the very essence of policymaking and power dynamics in modern states. For instance, policy analyses will always have to pay attention to the discrepancies between policy discourses, policies-on-paper and policies-in-practice. (2) 'Issue-specific' policy processes are inherently linked to what immigration does to state sovereignty and interest alignment, but are present across political regimes and vary according to the specific policy issue at stake. Take, for instance, bureaucratic dynamics. No matter whether in a democracy or autocracy, Ministries of Interior are likely to follow a security-driven agenda on irregular migration, while Ministries of Health might be more sympathetic to opening services to undocumented migrants given the imperative of securing public health. (3) Lastly, 'regime-specific' policy processes are intrinsically tied to specific features of political systems. These are the dynamics where the regime effect kicks in. For instance, the weight of legal actors in immigration policy is, by definition, more important in liberal democracies than in autocracies where judges are often not independent. Substantiating this three-fold typology could be one promising avenue to advance more systematic and fine-grained theory-building on migration politics.

The second research strategy is to focus on actual political practices and to deliberately design studies that compare cases across pre-determined categories. For example, Garcés-Mascareñas (2012) compared policies on (irregular) labour immigration in Malaysia and Spain, showing that policy practices on the ground did not differ as much as expected based on these countries' official policy documents. Also, scholars have investigated bottom-up mobilization on immigration in Israel and Singapore (Kemp and Kfir 2016) and in Morocco and Turkey (Üstübici 2015), differentiating civil society strategies that are at play across countries from those that are context-specific. Such studies make it possible to detect similarities in policymaking across political regimes and to unveil policy practices that were previously hidden - such as bottom-up, pro-migrant mobilization in autocracies and illiberal transnational policy dynamics in democracies.

A focus on political practices across pre-set regime types would ultimately allow the identification of autocratic practices in democracies and democratic practices in autocracies (Glasius 2018). What does this mean exactly? On the one hand, not all policy practices in democracies 
are in fact democratic, that is, subject to popular control or legislative approval. Executive orders or ministerial decrees, for instance, bypass discussions in parliament, among parties, or with the public. On immigration, travel visa requirements provide governments with a convenient tool to regulate immigration according to economic or diplomatic priorities, as they can be introduced or removed through executive measures and thus circumvent lengthy and politicized law-making procedures (de Haas et al. 2019). The decision of former US President Trump to use his executive powers and enact the so-called 'Muslim ban' (a visa ban for citizens coming from seven predominantly Muslim countries) through a presidential decree in January 2017 is a case in point. In addition, even within democracies with a strong rule of law and low corruption, there is always more leeway for informality and arbitrariness in policy implementation than suggested by research that looks at institutional decision-making only.

On the other hand, autocratic regimes also need to secure their domestic legitimacy by taking into account economic lobbies or public opinion (Brooker 2014; Bueno de Mesquita et al. 2003). This questions the widespread myth of the all-powerful dictator. The dynamics around visa liberalization in Ecuador illustrate this: only a few months after Ecuador removed visa restrictions for all nationalities in June 2008, the government reintroduced visas for citizens from specific countries, such as China, Afghanistan and Nigeria. As Freier (2013: 16) argued, despite the autocratic nature of the regime, "[President] Correa faced internal political pressure from within his administration, from the political opposition and the media to revoke universal visa freedom". In addition, research has revealed the limited, yet real margin of manoeuvre of civil society to lobby for migrants' rights in countries such as Morocco and Iran (Moghadam 2018; Üstübici 2015). This shows that even political contexts with limited freedom of expression offer opportunities for political action and for contesting formal institutions and policies.

These insights into democratic dynamics within autocracies and autocratic dynamics within democracies suggest that, when looking at political practices, there might be more similarities in migration politics than expected from a political regime perspective. Ultimately, states around the world are structured in strikingly similar ways: they are organized around ministries with distinct portfolios; separate executive, legislative, and judicial institutions (even if only on paper); and a bureaucratic apparatus that links central decision-makers and local implementers. Despite wide variations in how states work on the ground, state actors are always internally fragmented and pursue potentially diverging interests. Regardless of the political regime in place, more than one actor is involved in developing, taking, or implementing policy decisions, and each actor is faced with a range of policy options that cater to different economic, political or societal interests. As Castles (2004: 865) writes, "political systems are complex and contradictory in themselves $[\ldots]$ even less democratic receiving states find that migration control comes up against competing interests". It is in these spaces of competing interests that power dynamics unfold across political regimes and political geographies, and it is on these competing interests that research should focus.

In addition, all states - regardless of the political institutions in place - are operating within the same world system, characterized by globalized capitalist economies and neoliberal pressures on (labour) markets that structure interests on migration and, thus, migration policymaking, in fundamentally similar ways. These insights provide compelling reasons to question the assumption that immigration policymaking intrinsically differs across democratic and autocratic regimes, and to pay more attention to dynamics of convergence across and variation within polities. Such a research agenda would provide much-needed, novel perspectives on the inherent ambiguities and contradictions of real-life migration governance across the globe. 


\section{REFERENCES}

Acosta Arcarazo, D. and Freier, L. F. (2015), 'Turning the immigration policy paradox upside down? Populist liberalism and discursive gaps in South America', International Migration Review, 49 (3), 659-96.

Bakewell, O. (2009), 'South-South migration and human development: reflections on African experiences', Human Development Research Paper 2009/07, New York: United Nations Development Programme (UNDP).

Bhambra, G. K. (2014), Connected Sociologies, London: Bloomsbury Academic.

Bonjour, S. (2011), 'The power and morals of policy makers: reassessing the control gap debate', International Migration Review, 45(1), 89-122.

Boswell, C. (2007), 'Theorizing migration policy: is there a third way?' International Migration Review, 41(1), 75-100.

Brand, L. A. (2006), Citizens Abroad - Emigration and the State in the Middle East and North Africa, Cambridge: Cambridge University Press.

Brooker, P. (2014), Non-Democratic Regimes: Theory, Government, and Politics, Basingstoke: Palgrave Macmillan.

Bueno de Mesquita, B., A. Smith, R. M. Siverson and J. D. Morrow (2003), The Logic of Political Survival, Cambridge, MA: MIT Press.

Castles, S. (2004), 'The factors that make and unmake migration policies', International Migration Review, 38 (3), 852-84.

Chakrabarty, D. (2000), Provincializing Europe: Postcolonial Thought and Historical Difference, Princeton, NJ: Princeton University Press.

Chimni, B. S. (1998). 'The Geo-Politics of Refugee Studies: A View from the South', Journal of Refugee Studies, 11 (4): 350-374.

Comaroff, J. and J. L. Comaroff (2012), 'Theory from the South: or, how Euro-America is evolving toward Africa', Anthropological Forum, 22 (2), 113-31.

Connell, R. (2007), Southern Theory: The Global Dynamics of Knowledge in Social Science, Cambridge: Polity Press.

Czaika, M. and H. de Haas (2013), 'The effectiveness of immigration policies', Population and Development Review, 39 (3), 487-508.

de Haas, H., M. Czaika, M.-L. Flahaux, E. Mahendra, K. Natter, S. Vezzoli and M. Villares-Varela (2019), 'International migration: trends, determinants, and policy effects', Population and Development Review, 45 (4), 885-922.

de Haas, H., K. Natter and S. Vezzoli (2018), 'Growing restrictiveness or changing selection? The nature and evolution of migration policies', International Migration Review, 52 (2), 314-67.

de Haas, H. and S. Vezzoli (2011), 'Leaving matters: the nature, evolution and effects of emigration policies', International Migration Institute (IMI) Working Paper, https://www.migrationinstitute.org/ publications/wp-34-11.

FitzGerald, D. S. and D. Cook-Martín (2014), Culling the Masses: The Democratic Origins of Racist Immigration Policy in the Americas, Cambridge, MA: Harvard University Press.

Freeman, G. P. (1995), 'Modes of immigration politics in liberal-democratic states', International Migration Review, 29(4), 881-902.

Freier, L. F. (2013), 'Open doors (for almost all): visa policies and ethnic selectivity in Ecuador', London School of Economics (LSE) Working Paper 188, https://ccis.ucsd.edu/_files/wp188.pdf.

Gamlen, A. (2008), 'The emigration state and the modern geopolitical imagination', Political Geography, $27(8), 840-56$.

Garcés-Mascareñas, B. (2012), Labour Migration in Malaysia and Spain: Markets, Citizenship and Rights, Amsterdam: Amsterdam University Press.

Glasius, M. (2018), 'What authoritarianism is ... and is not: a practice perspective', International Affairs, 94 (3), 515-33.

Guiraudon, V. (1998), 'Third country nationals and European law: obstacles to rights expansion', Journal of Ethnic and Migration Studies, 24 (4), 657-74.

Hampshire, J. (2013), 'Immigration and the liberal state', in J. Hampshire (ed.), The Politics of Immigration, Cambridge: Polity Press, pp. 1-15. 
Hollifield, J. F. (1992), Immigrants, Markets, and States: The Political Economy of Postwar Europe, Cambridge, MA: Harvard University Press.

Joppke, C. (1998), 'Why liberal states accept unwanted immigration', World Politics, 50 (2), 266-93.

Kemp, A. and N. Kfir (2016), 'Mobilizing migrant workers' rights in "nonimmigration" countries: the politics of resonance and migrants' rights activism in Israel and Singapore', Law \& Society Review, 50 (1), 82-116.

Massey, D. S., J. Arango, G. Hugo, A. Kouaouci, A. Pellegrino and J. E. Taylor (1998), Worlds in Motion: Understanding International Migration at the End of the Millennium, Oxford: Clarendon Press.

Mignolo, W. D. (2002), 'The geopolitics of knowledge and the colonial difference', South Atlantic Quarterly, 101 (1), 57-96.

Milner, J. H. S. (2009). Refugees, the State and the Politics of Asylum in Africa, New York: Palgrave MacMillan.

Moghadam, A. (2018), 'Politics of citizenship and migration in a post-revolutionary Iran', paper presented at the The Politics of Migration Policies: Towards an Empirically Grounded, Comparative Political Theory of Migration Politics workshop, 17-18 December 2018, Paris, France.

Natter, K. (2018a), 'Autocratic immigration policymaking: the illiberal paradox hypothesis', IMIn Working Paper 147, https:/www.migrationinstitute.org/publications/autocratic-immigration -policymaking-the-illiberal-paradox-hypothesis.

Natter, K. (2018b), 'Rethinking immigration policy theory beyond "western liberal democracies", Comparative Migration Studies, 6 (4), 1-21.

Natter, K. (2021 forthcoming). 'Immigration policy adhocracy. How Morocco and Tunisia secure their state power over immigration', Territory, Politics and Governance.

Norman, K. P. (2016), 'Migration to MENA host states: examining engagement practices in Egypt, Morocco and Turkey', paper presented at the APSA 2016 Annual Meeting.

Paoletti, E. (2011), 'Migration and foreign policy: the case of Libya', Journal of North African Studies, 16 (2), 215-31.

Piore, M. J. (1979), Birds of Passage. Migrant Labor and Industrial Societies, Cambridge: Cambridge University Press.

Pomeranz, K. (2000), The Great Divergence: China, Europe, and the Making of the Modern World Economy, Princeton, NJ: Princeton University Press.

Ruhs, M. (2013), 'The rights of migrant workers reframing the debate', in The Price of Rights: Regulating International Labor Migration, Princeton, NJ: Princeton University Press, pp. 1-12.

Ruhs, M. and B. Anderson (2010), 'Semi-compliance and illegality in migrant labour markets: an analysis of migrants, employers and the state in the UK', Population Space and Place, 16 (3), 195-211.

Stel, N. (2020). Hybrid Political Order and the Politics of Uncertainty: Refugee Governance in Lebanon, Abingdon: Routledge.

Thiollet, H. (2016), 'Managing migrant labour in the Gulf: transnational dynamics of migration politics since the 1930s', IMI Working Paper 131, https://www.migrationinstitute.org/publications/managing -migrant-labour-in-the-gulf-transnational-dynamics-of-migration-politics-since-the-1930s.

Timmer, A. S. and J. G. Williams (1998), 'Immigration policy prior to the 1930s: labor markets, policy interactions, and globalization backlash', Population and Development Review, 24 (4), 739-71.

Torpey, J. (1997), 'Coming and going: on the state monopolization of the legitimate "means of movement", Sociological Theory, 16 (3), 239-59.

Torpey, J. (2000), The Invention of the Passport: Surveillance, Citizenship and the State, Cambridge: Cambridge University Press.

Tsourapas, G. (2019), 'The long arm of the Arab state', Ethnic and Racial Studies, 43 (2), 351-70.

Üstübici, A. (2015), 'The governance of international migration in Turkey and Morocco: irregular migrants' access to right to stay', PhD thesis, Koc University (Turkey) and University of Amsterdam (the Netherlands), Istanbul, Turkey.

Wallerstein, I. (1997), 'Eurocentrism and its avatars: the dilemmas of social science', Sociological Bulletin, 46 (1), 21-39.

Weber, M. (2009 [1919]), 'Politics as a vocation', in H. H. Gerth and W. C. Mills (eds), From Max Weber: Essays in Sociology, Abingdon: Routledge, pp. 77-128.

Zolberg, A. R. (1978), 'International migration policies in a changing world system', in W. H. McNeill and R. S. Adams (eds), Human Migration: Patterns and Policies, London: Indiana University Press, pp. 241-286. 